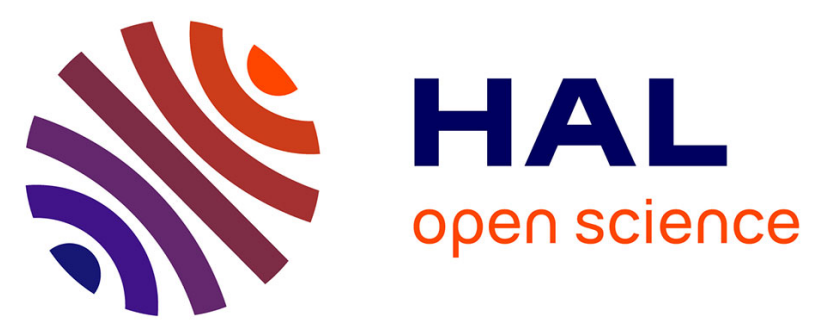

\title{
Effect of particle size on the biodistribution of lipid nanocapsules: Comparison between nuclear and fluorescence imaging and counting.
}

Samuli Hirsjärvi, Lucie Sancey, Sandrine Dufort, Camille Belloche, Claire Vanpouille-Box, Emmanuel Garcion, Jean-Luc Coll, François Hindré, Jean-Pierre Benoit

\section{To cite this version:}

Samuli Hirsjärvi, Lucie Sancey, Sandrine Dufort, Camille Belloche, Claire Vanpouille-Box, et al.. Effect of particle size on the biodistribution of lipid nanocapsules: Comparison between nuclear and fluorescence imaging and counting.. International Journal of Pharmaceutics, 2013, 453 (2), pp.594-600. 10.1016/j.ijpharm.2013.05.057 . inserm-00855672

\section{HAL Id: inserm-00855672 https://www.hal.inserm.fr/inserm-00855672}

Submitted on 29 Aug 2013

HAL is a multi-disciplinary open access archive for the deposit and dissemination of scientific research documents, whether they are published or not. The documents may come from teaching and research institutions in France or abroad, or from public or private research centers.
L'archive ouverte pluridisciplinaire HAL, est destinée au dépôt et à la diffusion de documents scientifiques de niveau recherche, publiés ou non, émanant des établissements d'enseignement et de recherche français ou étrangers, des laboratoires publics ou privés. 


\section{Effect of particle size on the biodistribution of lipid nanocapsules: comparison between nuclear and fluorescence imaging and counting}

Samuli Hirsjärvi ${ }^{\mathrm{a}, 1, *}$, Lucie Sancey ${ }^{\mathrm{b}, \mathrm{c}, 1}$, Sandrine Dufort $^{\mathrm{b}}$, Camille Belloche ${ }^{\mathrm{a}}$, Claire Vanpouille-

5 Box $^{\mathrm{a}, \mathrm{d}}$, Emmanuel Garcion ${ }^{\mathrm{a}}$, Jean-Luc Coll $^{\mathrm{b}}$, François Hindré $^{\mathrm{a}}$, Jean-Pierre Benoît ${ }^{\mathrm{a}}$

${ }^{a}$ LUNAM Université, Université d'Angers, INSERM U1066, Angers, France

${ }^{\mathrm{b}}$ INSERM-UJF-CRI-U823, Institut Albert Bonniot, La Tronche, France

${ }^{c}$ UMR 5306 CNRS - Université Claude Bernard Lyon 1, Laboratoire de Physico-Chimie des

10 Matériaux Luminescents, Villeurbanne, France

${ }^{\mathrm{d}}$ Present affiliation: New York University School of Medicine, Department of Pathology, New York, NY, USA

${ }^{1}$ Equal contribution

$15{ }^{*}$ Corresponding author (S. Hirsjärvi): samuli.hirsjarvi@ univ-angers.fr, tel.: +33 2446885 45; fax: +33 2446885 46; address: INSERM U1066, IBS-CHU Angers, 4 rue Larrey, 49933 Angers, France. 


\section{Abstract}

20

In vivo biodistribution of nanoparticles depends on several physicochemical parameters such as size. After intravenous injection of 25, 50 and $100 \mathrm{~nm}$ lipid nanocapsules (LNC) in nude mice bearing HEK293( $\left.\beta_{3}\right)$ tumour xenografts, biodistribution was evaluated by $\gamma$-scintigraphy and by $\gamma$ counting. The small LNC $25 \mathrm{~nm}$ disappeared faster than the larger LNC 50 and $100 \mathrm{~nm}$ from the

25 blood circulation due to faster elimination and wider tissue distribution. At $24 \mathrm{~h}$, biodistribution profiles of all these LNC were similar. Low LNC quantities were found in this weak EPR (enhanced permeability and retention) tumour regardless the particle size. Co-injected $50 \mathrm{~nm}$ fluorescent DiD-LNC and ${ }^{99 \mathrm{~m}} \mathrm{Tc}-\mathrm{LNC}$ allowed direct comparison of biodistribution as evaluated by the two methods. Optical imaging underestimated LNC quantity especially in dark-coloured organs

30 that were observed to capture extensive quantities of the particles by $\gamma$-counting (i.e. liver, spleen, and kidney).

Keywords: lipid nanocapsules, biodistribution, $\gamma$-scintigraphy, optical imaging, fluorescence 
Extensive studying of nanoparticles during the last decades has resulted in drug delivery systems that protect the active substance, improve solubility and carry the drug to specific tissues in the body (Farokhzad and Langer, 2009). Cancer therapy is one of the areas that benefit considerably

40 from these advances (Hirsjärvi et al., 2011). In order to develop an efficient nanoparticulate drug delivery system, its pharmacokinetic profile as well as biodistribution should be evaluated when the system is transferred from in vitro assays to first preclinical tests. Molecular imaging offers tools for non-invasive evaluation (Baker, 2010), and the same probes used also allow tissue distribution determination after animal sacrifice. Commonly used small animal imaging technologies include Xray computed tomography (CT), magnetic resonance imaging (MRI), positron emission tomography (PET), single photon emission computed tomography (SPECT) and different optical imaging techniques (Dufort et al., 2010). Optical imaging techniques are sensitive, non-ionizing, fast and easy to perform, portative and cheap. However, quantitative performance of optical techniques still needs improvement in order to overcome the problems of absorption and autofluorescence. SPECT can overcome optical imaging problems because it provides more reliable quantitative information about physiological functions at the molecular level and it is, thus, well suited for monitoring many vital processes such as blood flow and perfusion, receptor-ligand binding rates, and oxygen utilization. SPECT has no depth limit but the acquisition times might be from several minutes up to hours. However, SPECT suffers from some noteworthy other disadvantages such as the need of 55 radiolabelled particles, and adapted and expensive devices. Both SPECT and optical imaging possess a resolution of $1 \mathrm{~mm}$ (for more detail, please see (Dufort et al., 2010)).

Biocompatible nanoparticles for drug delivery are usually made of polymer or lipid materials (Kumari et al., 2010; Müller et al., 2011; Torchilin, 2007; Torchilin, 2005). Lipid nanocapsules 
60 (LNC) are synthetic particles having a hybrid structure between polymer nanoparticles and liposomes (Heurtault et al., 2002). LNC consist of low-toxicity materials (PEGylated surfactant, lecithin, triglycerides) and their fabrication, based on low-energy organic solvent-free phase inversion process, can be easily scaled up. By changing proportions of the components, the LNC size can be tuned within the range of 20-100 nm (Heurtault et al., 2003). LNC have been applied 65 e.g. in the delivery of cancer therapeutics (Cirpanli et al., 2011; Garcion et al., 2006; Lacoeuille et al., 2007; Paillard et al., 2010; Peltier et al., 2006; Weyland et al., 2011) and other drug molecules (Lamprecht et al., 2004) as well as macromolecules such as siRNA and DNA (Morille et al., 2010; Morille et al., 2011). Because of their semi-rigid shell, LNC can be modified by post-inserting amphiphilic molecules. This kind of post-insertion allows for e.g. improvement of biodistribution 70 profiles (Hoarau et al., 2004; Morille et al., 2010) or creation of templates for further attachment of active targeting ligands (Béduneau et al., 2008; Béduneau et al., 2007; Bourseau-Guilmain et al., 2012). Radioactive molecules such as ${ }^{99 \mathrm{~m}} \mathrm{Tc}$ and ${ }^{188} \mathrm{Re}$ have been successfully encapsulated in LNC as forms of lipophilic complexes (Ballot et al., 2006). These kinds of radio-labelled LNC can be used in biodistribution studies, imaging purposes and in radiotherapy (Allard et al., 2008; Ballot et 75 al., 2006; Vanpouille-Box et al., 2011a; Vanpouille-Box et al., 2011b).

In a previous study, we have evaluated the biodistribution profile of LNC of three different sizes (25, 50 and $100 \mathrm{~nm}$ ) with the help of an optical imaging technique, fluorescence reflectance imaging (2D-FRI) (Hirsjärvi et al., 2013). Nude mice bearing subcutaneous HEK293( $\left.\beta_{3}\right)$ (human 80 embryonic kidney) xenografts were used in the study. Images taken at 1.5-3 $\mathrm{h}$ after intravenous injection revealed that fluorescence staining of the smallest LNC (25 nm) was more homogeneous throughout the mice than the staining of the bigger LNC: the 50 and $100 \mathrm{~nm} \mathrm{LNC}$ were found mostly in the liver. However, when the mice were sacrificed after $24 \mathrm{~h}$, tissue distribution profiles, 
evaluated by fluorescence intensity, were similar for the three LNC sizes. With all three sizes, tumour could be distinguished from the images.

In the present study, to get more quantitative information about LNC pharmacokinetics and biodistribution, ${ }^{99 \mathrm{~m}}$ Tc-labelled $\mathrm{LNC}$ of the same three sizes $(25,50$ and $100 \mathrm{~nm})$ were injected intravenously in nude mice bearing the same tumour model (HEK293( $\left.\beta_{3}\right)$ xenografts). $\gamma$ -

90 Scintigraphy was performed at different time points up to $24 \mathrm{~h}$ together with tissue distribution determination by $\gamma$-counting at $1.5,4$ and $24 \mathrm{~h}$. To compare the performance of $2 \mathrm{D}$-FRI imaging (region of interest (ROI) drawing around each organ from the images taken with a fluorescence camera) and $\gamma$-counting in the determination of tissue distribution, mice were co-injected a mixture of fluorescence-labelled (DiD) and ${ }^{99 \mathrm{~m}}$ Tc-labelled $\mathrm{LNC}$ of one chosen size $(50 \mathrm{~nm})$.

95

\section{Materials and Methods}

\subsection{Materials}

Solutol® HS15 (PEG 660 12-hydroxystearate, $M_{\mathrm{W}} \sim 870$ Da) (BASF, Ludwigshafen, Germany), Labrafac $^{\text {TM }}$ WL 1349 (caprylic/capric acid triglycerides) (Gattefossé S.A., Saint-Priest, France), Lipoid® S75-3 ( $\left.M_{\mathrm{W}} \sim 780 \mathrm{Da}\right)$ (Lipoid GmbH, Ludwigshafen, Germany), NaCl (Prolabo VWR International, Fontenay-sous-Bois, France) and deionized MilliQ185 water (Waters, Saint-Quentinen-Yveline, France) were used in the LNC preparation. 1,1'-dioctadecyl-3,3,3',3'tetramethylindodicarbocyanine perchlorate (DiD) was from Invitrogen (Cergy Pontoise, France). 


\subsection{Methods}

110

\subsubsection{Preparation of the ${ }^{99 m}$ Tc-SSS complex}

Pertechnetate $\left({ }^{99 \mathrm{~m}} \mathrm{TcO}_{4}{ }^{-}\right)$was obtained from the University Hospital of Angers (CHU Angers, France). The ${ }^{99 \mathrm{~m}}$ Tc-SSS complex (bis (perthiobenzoato) (dithiobenzoato) technetium(III) 115 heterocomplex) was prepared according to the following method (Ballot et al., 2006; Mévellec et al., 2002): $750 \mathrm{MBq}$ of ${ }^{99 \mathrm{~m}} \mathrm{TcO}_{4}{ }^{-}$in $0.5 \mathrm{~mL} 0.9 \% \mathrm{NaCl}$ was added to a freeze-dried formulation kit containing $30 \mathrm{mg}$ sodium gluconate, $30 \mathrm{mg}$ ascorbic acid, $40 \mathrm{mg}$ potassium oxalate, and $4 \mathrm{mg}$ $\mathrm{SnCl}_{2} \cdot 2 \mathrm{H}_{2} \mathrm{O}$ reconstituted in $0.5 \mathrm{~mL} 0.9 \% \mathrm{NaCl}$, and the solution was mixed for 15 minutes at room temperature. Then, $20 \mathrm{mg}$ of sodium dithiobenzoate ligand (in $0.5 \mathrm{~mL}, \mathrm{pH}$ 7) (Platform of Organic

120 Synthesis, Rennes, France) was added and the mixture was heated at $100{ }^{\circ} \mathrm{C}$ for 30 minutes, which allowed formation of the ${ }^{99 \mathrm{~m}} \mathrm{Tc}-\mathrm{SSS}$ complex. The complex was extracted with dichloromethane (1 $\mathrm{mL}$ ) and washed three times with $1 \mathrm{~mL}$ water.

\subsubsection{LNC preparation and characterization}

125

LNC were prepared by the phase inversion temperature method described by Heurtault et al. (Heurtault et al., 2003). Solutol®, Lipoid®, Labrafac $\AA, \mathrm{NaCl}$ and water were mixed and the ${ }^{99 \mathrm{~m}} \mathrm{Tc}$ SSS complex in dichloromethane $\left({ }^{99 \mathrm{~m}} \mathrm{Tc}-\mathrm{LNC}\right)$ or DiD in acetone (DiD-LNC) was added to this mixture. When preparing fluorescent $\mathrm{LNC}$, final concentration of $\mathrm{DiD}$ was $3 \mathrm{mmol} / \mathrm{L} /$ total 130 Labrafac $®$ amount. Dichloromethane/acetone was evaporated by heating at $60{ }^{\circ} \mathrm{C}$ for 15 min under stirring. The formulation was heated to $85^{\circ} \mathrm{C}$ at a rate of $5^{\circ} \mathrm{C} / \mathrm{min}$ followed by cooling at the same rate to $65{ }^{\circ} \mathrm{C}$. This cycle was repeated twice. During the last decrease of temperature, at $78{ }^{\circ} \mathrm{C}$ (during the phase inversion zone), the system was diluted with $4.2 \mathrm{~mL}$ cold $\left(4{ }^{\circ} \mathrm{C}\right)$ water leading to 
formation of stable LNC. Size of the $\operatorname{LNC}(25,50,100 \mathrm{~nm})$ was adjusted by changing the proportions of the components (Table 1).

Size distributions and zeta $(\zeta)$ potentials of LNC were determined with a Zetasizer ZS (Malvern, Worcestershire, UK). Particle sizing was based on photon correlation spectroscopy (PCS); the results were analyzed by CONTIN algorithm and the sizes were presented based on the volume 140 distributions together with polydispersity indices (PdI). Electrophoretic mobilities were converted to $\zeta$-potentials using Smoluchowski’s equation.

\subsubsection{Cells}

145 HEK293 $\left(\beta_{3}\right)$ cells, stable transfectants of human $\beta_{3}$ from the human embryonic kidney cell line (kindly provided by J.-F. Gourvest, Aventis, France), were cultured in DMEM supplemented with $1 \%$ glutamine, $10 \%$ fetal bovine serum (FBS), 50 units $/ \mathrm{mL}$ penicillin, $50 \mu \mathrm{g} / \mathrm{mL}$ streptomycin, and $700 \mu \mathrm{g} / \mathrm{mL}$ Geneticin (G418 sulfate, Gibco, Paisley, UK), at $37{ }^{\circ} \mathrm{C}$ in a humidified $95 \%$ air / 5\% $\mathrm{CO}_{2}$ atmosphere.

150

\subsubsection{In vivo imaging and biodistribution study}

The animal experiments were performed in agreement with the EU Directive 2010/63/EU for animal experiments, and the "Principles of Laboratory Animal Care" (NIH Publication no. 86-23, 155 revised 1985), and the experimental protocol was approved by the local ethics committee.

40 female NMRI nude mice (5 weeks old, JANVIER, Le Genest Saint Isle, France) were injected subcutaneously with HEK293 $\left(\beta_{3}\right)$ cells $\left(1 \times 10^{7} /\right.$ mouse). After tumor growth $(\sim 4$ weeks $)$, mice 
were anesthetized with a mixture of ketamine $(100 \mu \mathrm{g} / \mathrm{g}) /$ medetomidine $(0.2 \mu \mathrm{g} / \mathrm{g})$ by an intraperitoneal injection, and then $200 \mu \mathrm{L}$ of LNC (about $100 \mathrm{mg} / \mathrm{mL}$ ) were injected intravenously in the tail vein. Thus, each mouse obtained a dose of about $26 \mathrm{MBq}{ }^{99 \mathrm{~m}} \mathrm{Tc}\left({ }^{99 \mathrm{~m}} \mathrm{Tc}-\mathrm{LNC}\right)$. The mice which were injected by the mixture radio- and fluorescence-labelled LNC obtained $100 \mu \mathrm{L}$ of ${ }^{99 m} \mathrm{Tc}-\mathrm{LNC}(13 \mathrm{MBq})$ and $100 \mu \mathrm{L}$ of DiD-LNC (same quantity of both LNC).

165 In $\gamma$-scintigraphy, the injected mice were visualized under a clinical $\gamma$-camera (Sopha Medical DSXi, $140 \mathrm{keV} \pm 15 \%, 128^{2}$ matrix, HRLE collimator). Static 15 min scintigraphic images were registered at $1.5 \mathrm{~h}, 3 \mathrm{~h}, 5 \mathrm{~h}$, and $24 \mathrm{~h}$ (a video clip of dynamic $30 \mathrm{~s}$ scintigraphic acquisitions collected until 90 min post-injection is available as Supporting Content). To study tissue distribution of LNC, the animals were sacrificed at $1.5 \mathrm{~h}(\mathrm{n}=4), 4 \mathrm{~h}(\mathrm{n}=4)$, and $24 \mathrm{~h}(\mathrm{n}=4)$ after injection. The organs/tissues were removed, rinsed, and weighed. Activity of each removed organ was determined using a $\gamma$-counter (Packard Auto-Gamma 5,000 series).

Fluorescent images were acquired by a back-thinned CCD camera at $-80^{\circ} \mathrm{C}$ (ORCAII-BT-512G, Hamamatsu, Massy, France). Image display and analysis of the dissected organs were performed using the Wasabi software (Hamamastsu, Massy, France). Semi-quantitative data were obtained by drawing regions of interest (ROI) around each organ. The results of organ fluorescence quantifications were expressed as number of relative light units (RLU)/pixel.

When imaging and quantifying the mice that obtained the mixture of radio- and fluorescencelabelled LNC, fluorescence acquisitions were performed before scintigraphic acquisitions and $\gamma$ counting. 


\subsubsection{Statistical analysis}

185

Biodistribution data was analyzed using one-way ANOVA with Tukey's multiple comparison test (Prism, GraphPad Software, Inc., La Jolla, CA). $p<0.05$ was considered as statistically significant.

\section{Results}

190

\subsection{LNC preparation}

Size and $\zeta$-potential of ${ }^{99 \mathrm{~m}} \mathrm{Tc}-\mathrm{LNC}$ are presented in Table 2. These characteristics of DiD-LNCs were identical with ${ }^{99 \mathrm{~m}}$ Tc-LNC (Hirsjärvi et al., 2013). PdI-values of all three types of LNC were

195 low indicating homogeneous size distributions. Slightly negative $\zeta$-potential of LNC originates from PEG groups at the surface forming dipoles able to interact with counterions or water dipoles (Vonarbourg et al., 2005). Encapsulation of lipophilic ${ }^{99 \mathrm{~m}} \mathrm{Tc}$ or DiD in the oily core of LNC did change neither size nor $\zeta$-potential of the blank LNC as reported earlier (Ballot et al., 2006; Morille et al., 2010; Paillard et al., 2010; Zou et al., 2008).

\subsection{In vivo biodistribution of ${ }^{99 m} T c-L N C$}

Biodistribution of 25,50 , and $100 \mathrm{~nm}{ }^{99 \mathrm{~m}} \mathrm{Tc}-\mathrm{LNC}$ in different organs $1.5 \mathrm{~h}, 4 \mathrm{~h}$ and $24 \mathrm{~h}$ after i.v. injections are presented in Figure 1. LNC $25 \mathrm{~nm}$ disappeared quickly from the blood circulation: 3$2056 \%$ total CPM (counts per minute) / $\mathrm{g}$ of the $25 \mathrm{~nm} \mathrm{LNC}$ was found in the blood at $1.5-4 \mathrm{~h}$ whereas the measured blood activities for LNC 50/100 nm were about $25-30 \%$ at the same time points $(p<$ 0.001: LNC $25 \mathrm{~nm} v$ s. LNC 50/100 nm). Conversely, at $24 \mathrm{~h}$, total CPM / g of LNC $25 \mathrm{~nm}$ was higher $(\sim 3 \%)$ than the corresponding LNC 50/100 nm values $(\sim 1.5 \%$; $p<0.01)$. More activity of 
LNC $25 \mathrm{~nm}$ was found in the liver at $1.5-4 \mathrm{~h}(\sim 28 \%)$ compared to LNC $50 \mathrm{~nm}(16-18 \% ; p<0.01)$ and LNC $100 \mathrm{~nm}$ (21-22\%; difference not significant). Also, compared to LNC 50/100 nm, more LNC $25 \mathrm{~nm}$ were found in the heart and in the lung $(p<0.01)$, and in the adrenal at $1.5-4 \mathrm{~h}$. In contrast, at $24 \mathrm{~h}$, less LNC $50 \mathrm{~nm}$ was found in the heart, lung and kidney compared to LNC 25/100 $\mathrm{nm}(p<0.05)$. The spleen captured less LNC $50 \mathrm{~nm}$ than LNC 25/100 nm at $1.5 \mathrm{~h}$ and $4 \mathrm{~h}(p<$ 0.05). No significant differences were found in the tumour accumulation between the three particle 215 sizes at different time points (1-3\% total CPM / g). Otherwise, distribution in other organs was similar at different time points.

$\gamma$-Scintigraphic images of mice $1.5 \mathrm{~h}, 3 \mathrm{~h}, 5 \mathrm{~h}$, and $24 \mathrm{~h}$ after i.v. injection of 25, 50 and $100 \mathrm{~nm}$

${ }^{99 \mathrm{~m}} \mathrm{Tc}-\mathrm{LNC}$ are presented in Figure 2. The livers were well visible at $24 \mathrm{~h}$. At earlier time points, especially at $1.5 \mathrm{~h}$ and $3 \mathrm{~h}$, more vertical highlighted regions revealed also radioactivity in the blood circulation (heart, lungs). LNC $25 \mathrm{~nm}$ were better observable than LNC 50/100 nm in peripheral regions and at intestinal area of mice at $3 \mathrm{~h}$ and $5 \mathrm{~h}$. These observations were supported by the $\gamma$ counting results: if the values "\% CPM of all organs" were not corrected by the organ masses, radioactivity in the carcass after the injection of LNC $25 \mathrm{~nm}$ were $39 \%$ at $1.5 \mathrm{~h}$ and $37 \%$ at $4 \mathrm{~h}$.

225 Corresponding values for LNC 50 and $100 \mathrm{~nm}$ were 22\% ( $p<0.001$ vs. LNC $25 \mathrm{~nm})$ and 22\% $(p<$ $0.001) ; 15 \%(p<0.01)$ and $18 \%(p<0.05)$ at $1.5 \mathrm{~h}$ and $4 \mathrm{~h}$, respectively. Also, at $4 \mathrm{~h}, 7.5 \%$ of LNC $25 \mathrm{~nm}$ were found in the intestine vs. $4.5 \%$ of LNC $50 \mathrm{~nm}$ and $3 \%$ of LNC $100 \mathrm{~nm}$ (both $p<0.01$ vs. LNC $25 \mathrm{~nm})$.

An example of fluorescence images of a mouse $24 \mathrm{~h}$ after injection of a $50 \%-50 \%$ mixture of $50 \mathrm{~nm}$ DiD-LNC and ${ }^{99 \mathrm{~m}} \mathrm{Tc}-\mathrm{LNC}$ is presented in Figure 3. Fluorescence staining allowed identifying of the 
liver (A) and the tumour (B). LNC biodistribution in different organs at $24 \mathrm{~h}$ is presented in Figure

235 4. To better compare the quantification by the two techniques ( $\gamma$-counting and fluorescence imaging), the organ data were normalized by the detected radioactivity (\% ID/g) and fluorescence intensity (RLU/pixel/20 ms) in the bone. As already observed when testing radiolabelled LNC of different sizes, the majority of radioactivity was found in the liver as well as in the adrenal, spleen, and kidneys (Fig. 4A). Instead, the observed fluorescence intensity was also highest in the liver, but

240 the next highest fluorescent organs were the ovaries, adrenal, and skin. The global fluorescence intensity in the spleen was low, and moderate in the kidneys. Radioactivity in relation to other organs was clearly higher in the liver, adrenal, spleen, kidney, ovary, and lung. No such clear differences were observed in fluorescence intensities. An image of the organs (Fig. 4B), used for the quantification, reveals well the highly fluorescent organs.

\section{Discussion}

Generally, sub-100 nm nanoparticles are expected to circulate longer time in the blood compared to $>100 \mathrm{~nm}$ particles (Vonarbourg et al., 2006). However, in the size range of 10-100 nm, surface and even elasticity properties of nanoparticles as well as their mechanism of elimination have been shown to dictate pharmacokinetic and biodistribution profiles. Also, animal model (mouse/rat) is known to affect tissue distribution (Sun et al., 2005). For example, systemic clearance and volume of distribution of $60 \mathrm{~nm}$ PEGylated polyacrylate nanoparticles in mice were significantly lower when compared to $20 \mathrm{~nm}$ particles, leading to lower liver uptake ( 15\% ID/g at $48 \mathrm{~h})$ of the larger

$25560 \mathrm{~nm}$ particles (Yang et al., 2009). Similarly, $25 \mathrm{~nm}$ polymer micelles exhibited much shorter circulation half-lives than $60 \mathrm{~nm}$ micelles $\left(2.2\right.$-fold decrease in the distribution phase $\left.t_{1 / 2}\right)$ (Lee et al., 2010). More efficient clearance by hepatobiliary excretion of the smaller micelles was proposed as $\sim 70 \%$ of the (mouse) liver fenestrations are narrower than $100 \mathrm{~nm}$. The longest blood half-life of 
10-100 nm PEGylated gold nanoparticles was achieved with $\sim 60 \mathrm{~nm}$ particles by adjusting the size and PEG length (Perrault et al., 2009). On the other hand, mice plasma clearance rates (12\% ID/mL plasma at $24 \mathrm{~h})$, and the quantities in kidney ( 4\% ID/g), liver (10-16\% ID/g) and in spleen (5-10\% ID/g) were similar regardless of the polymer micelle size (30-100 nm) (Cabral et al., 2011). Several studies have proposed wider distribution, extravasation, of nanoparticles in different organs, the smaller the particle size was in the sub-100 nm range (De Jong et al., 2008; Hirn et al., 2011;

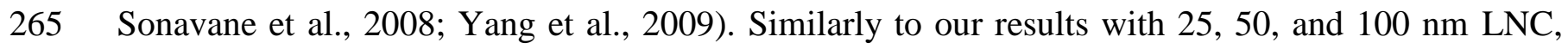
shortened blood circulation time is frequently related to this wider biodistribution. Higher quantity of LNC $25 \mathrm{~nm}$ in the liver $(1.5,4 \mathrm{~h}$ ) compared to LNC 50/100 $\mathrm{nm}$ in the current study indicated also faster hepatic accumulation. Radioactivity found in the kidneys can be explained by LNC accumulation. To undergo a complete renal clearance, the nanoparticle size should be less than 10 nm (Choi et al., 2007). Instead, 75 $\pm 25 \mathrm{~nm}$ PEGylated gold nanoparticles are reported to enter the fenestrated glomerular endothelia (80-100 $\mathrm{nm}$ pores) and accumulate in the kidney mesangium (Choi et al., 2011). Nanoparticle accumulation in the ovaries, clearly visible in the case of LNC (Fig. 4), is assumed to originate from fast growing and, thus, highly vascularized nature of the ovarian corpus luteum of mature female mice that leads to the EPR (enhanced permeability and 275 retention) effect, described initially for tumours (Schädlich et al., 2012).

In our previous study, after i.v. injection, signals of fluorescent-labelled LNC $25 \mathrm{~nm}$ in the skin and in the intestine were found to be more intense than the corresponding signals of LNC 50/100 nm (Hirsjärvi et al., 2013). Thus, the results of the current study confirmed these findings. Almost twice 280 the radioactivity of LNC $25 \mathrm{~nm}$ in carcass compared to LNC 50/100 $\mathrm{nm}$ at $1.5-4 \mathrm{~h}$ indicated, indeed, that the smallest LNC were distributed rapidly to the peripheral capillaries and probably perfused further to tissues increasing the skin fluorescence. Higher LNC $25 \mathrm{~nm}$ quantities in the intestine suggested more pronounced hepato-biliary evacuation. Differences in the elimination rate 
of the three LNC could not be, however, revealed when estimated injected doses were compared to 285 CPM of all organs. For each LNC type, differences between the different time points remained within $10 \%$ and were not significantly different.

Magnitude of the tumour accumulation of nanoparticles by the EPR effect together with a therapeutic effect (of an encapsulated drug) remains in general in the range of $3.5-12 \%$ (ID/g) (de Wolf et al., 2007; Kircheis et al., 2002; Kursa et al., 2002; Meng et al., 2011). Accumulation of LNC 25-100 nm in HEK293( $\left.\beta_{3}\right)$ tumour was a bit lower (1-3\%). It should be noted, however, that this subcutaneous model is an "EPR-weak" tumour having well-structured, neo-angiogenic vasculature with tight endothelial junctions (Jin et al., 2007; Razkin et al., 2006).

$295 \gamma$-Imaging of dual-labelled (radio+fluorescence) PEGylated polyacrylate nanoparticles revealed radioactivity in the cardiac area at early observation time points $(5 \mathrm{~min}-4 \mathrm{~h}$ ) followed by increasing activity in liver and spleen up to $48 \mathrm{~h}$ (Yang et al., 2009). Tumour was poorly observable by $\gamma$-imaging but, instead, optical imaging that enhanced subcutaneous signal compared to deep signals, showed clear fluorescence staining in tumour. Subcutaneous tumours were well visualized 300 by strongly surface-weighted optical imaging. Therefore, as in our studies ((Hirsjärvi et al., 2013) and the current study), optical imaging offers better resolution imaging especially for superficial organs whereas $\gamma$-scintigraphy recapitulates the global biodistribution of radiolabelled compounds in both internal and superficial organs.

305 To better compare the biodistribution of LNC measured by the two techniques, radioactivity and fluorescence intensity, the corresponding results were normalized by the value observed in the bone. The bone was selected because its radioactivity / fluorescence intensity level was observed to be settled in the middle of all analysed organs, allowing, thus, distinct representation of the data. In 
order to quantify fluorescence intensity of dissected organs, graphical ROI estimation from images visualized by a fluorescent camera is commonly performed. (Goutayer et al., 2010; Kim et al., 2010; Na et al., 2011; Sancey et al., 2009; Schädlich et al., 2011a; Schädlich et al., 2011b; Yang et al., 2007). Alternatively, homogenization of each dissected organ followed by determination of the fluorescence intensity on a microtiter plate can be done (He et al., 2010; Meng et al., 2011). The fluorescence intensity technique (ROI drawing and estimation), compared to $\gamma$-counting,

315 underestimated the LNC proportion in all the red and the dark red organs such as RES organs (liver, lung, spleen), and the kidney and adrenal. These organs are characterized by high blood perfusion. Similarly to our findings, ex vivo quantification of fluorescence intensity underestimated the uptake of polymer micelles in the liver, spleen, kidney, and also in the heart (Yang et al., 2007). For this reason, relative fluorescence intensity in other organs was found to be emphasized. Because of the

320 fluorescence quantification technique in this study, intensities of thin organs (i.e. skin) were also slightly highlighted. It should be noted that direct comparison of the two quantification techniques after normalization (Fig. 4) is not recommendable but, instead, this approach revealed well the relative differences between the organs within each technique.

\section{Conclusions}

Biodistribution studies of radiolabelled ${ }^{99 \mathrm{~m}} \mathrm{Tc}-\mathrm{LNC}$ in nude mice with subcutaneous HEK293( $\left.\beta_{3}\right)$ xenografts revealed that the majority of the smallest studied particles $(25 \mathrm{~nm})$ disappeared quickly from the blood circulation within $1.5 \mathrm{~h}$ after the intravenous injection due to wider tissue 330 distribution and faster elimination. Instead, 50 and $100 \mathrm{~nm} \mathrm{LNC} \mathrm{remained} \mathrm{in} \mathrm{the} \mathrm{circulation} \mathrm{at} \mathrm{least}$ up to $4 \mathrm{~h}$. At $24 \mathrm{~h}$, biodistribution profiles of the all LNC were similar. Tumour accumulation of LNC in this EPR-weak tumour was low regardless the size. When biodistribution profiles of coinjected $50 \mathrm{~nm}$ fluorescent DiD-LNC and ${ }^{99 \mathrm{~m}} \mathrm{Tc}-\mathrm{LNC}$ after animal sacrifice were compared, 
underestimating tendency of fluorescence detection of LNC accumulation in highly-capturing and

335 perfused organs (liver, adrenal, spleen, kidney, lung) was clearly observed but fluorescence detection allowed visualization of the tumour area. In following studies, we will further concentrate on the comparison of the two imaging / biodistribution evaluation techniques with the help of duallabelled nanocarriers and different tumour models.

\section{Acknowledgements}

This work was financially supported by the French National Research Agency (ANR) in the frame of its programme in Nanosciences and Nanotechnologies (CALIF project no. ANR-08-NANO-006).

\section{References}

Allard, E., Hindre, F., Passirani, C., Lemaire, L., Lepareur, N., Noiret, N., Menei, P., Benoit, J.P., 2008. Re-188-loaded lipid nanocapsules as a promising radiopharmaceutical carrier for internal radiotherapy of malignant gliomas. Eur J Nucl Med Mol Imag 35, 1838-1846.

350 Baker, M., 2010. Whole-animal imaging: the whole picture. Nature 463, 977-980.

Ballot, S., Noiret, N., Hindré, F., Denizot, B., Garin, E., Rajerison, H., Benoit, J.-P., 2006. ${ }^{99 \mathrm{~m}} \mathrm{Tc} /{ }^{188} \mathrm{Re}$-labelled lipid nanocapsules as promising radiotracers for imaging and therapy: Formulation and biodistribution. Eur J Nucl Med Mol Imag 33, 602-607.

Béduneau, A., Hindré, F., Clavreul, A., Leroux, J.-C., Saulnier, P., Benoit, J.-P., 2008. Brain targeting using novel lipid nanovectors. J Control Release 126, 44-49.

Béduneau, A., Saulnier, P., Hindré, F., Clavreul, A., Leroux, J.-C., Benoit, J.-P., 2007. Design of targeted lipid nanocapsules by conjugation of whole antibodies and antibody Fab' fragments. Biomaterials 28, 4978-4990.

Bourseau-Guilmain, E., Béjaud, J., Griveau, A., Lautram, N., Hindré, F., Weyland, M., Benoit, J.P., Garcion, E., 2012. Development and characterization of immuno-nanocarriers targeting the cancer stem cell marker AC133. Int J Pharm 423, 93-101.

Cabral, H., Matsumoto, Y., Mizuno, K., Chen, Q., Murakami, M., Kimura, M., Terada, Y., Kano, M.R., Miyazono, K., Uesaka, M., Nishiyama, N., Kataoka, K., 2011. Accumulation of sub$100 \mathrm{~nm}$ polymeric micelles in poorly permeable tumours depends on size. Nature

$365 \quad$ Nanotechnol 6, 815-823.

Choi, C.H.J., Zuckerman, J.E., Webster, P., Davis, M.E., 2011. Targeting kidney mesangium by nanoparticles of defined size. PNAS 108, 6656-6661.

Choi, H.S., Wenhao, L., Misra, P., Tanaka, E., Zimmer, J.P., Ipe, B.I., Bawendi, M.G., Frangioni, J.V., 2007. Renal clearance of quantum dots. Nat Biotech 25, 1165-1170. 
Cirpanli, Y., Allard, E., Passirani, C., Bilensoy, E., Lemaire, L., Calis, S., Benoit, J.-P., 2011. Antitumoral activity of camptothecin-loaded nanoparticles in 9L rat glioma model. Int $\mathbf{J}$ Pharm 403, 201-206.

De Jong, W.H., Hagens, W.I., Krystek, P., Burger, M.C., Sips, A.J.A.M., Geertsma, R.E., 2008. Particle size-dependent organ distribution of gold nanoparticles after intravenous administration. Biomaterials 29, 1912-1919.

de Wolf, H.K., Snel, C.J., Verbaan, F.J., Schiffelers, R.M., Hennink, W.E., Storm, G., 2007. Effect of cationic carriers on the pharmacokinetics and tumor localization of nucleic acids after intravenous administration. Int J Pharm 331, 167-175.

Dufort, S., Sancey, L., Wenk, C., Josserand, V., Coll, J.L., 2010. Optical small animal imaging in the drug discovery process. Biochim Biophys Acta 1798, 2266-2273.

Farokhzad, O.C., Langer, R., 2009. Impact of nanotechnology on drug delivery. ACS Nano 3, 1620.

Garcion, E., Lamprecht, A., Heurtault, B., Paillard, A., Aubert-Pouessel, A., Denizot, B., Menei, P., Benoit, J.P., 2006. A new generation of anticancer, drug-loaded, colloidal vectors reverses multidrug resistance in glioma and reduces tumor progression in rats. Mol Cancer Ther 5, 1710-1722.

Goutayer, M., Dufort, S., Josserand, V., Royère, A., Heinrich, E., Vinet, F., Bibette, J., Coll, J.-L., Texier, I., 2010. Tumor targeting of functionalized lipid nanoparticles: Assessment by in vivo fluorescence imaging. Eur J Pharm Biopharm 75, 137-147.

He, C., Hu, Y., Yin, L., Tang, C., Yin, C., 2010. Effects of particle size and surface charge on cellular uptake and biodistribution of polymeric nanoparticles. Biomaterials 31, 3657-3666.

Heurtault, B., Saulnier, P., Pech, B., Proust, J.-E., Benoit, J.-P., 2002. A novel phase inversionbased process for the preparation of lipid nanocarriers. Pharm Res 19, 875-880.

Heurtault, B., Saulnier, P., Pech, B., Venier-Julienne, M.-C., Proust, J.-E., Phan-Tan-Luu, R., Benoit, J.-P., 2003. The influence of lipid nanocapsule composition on their size distribution. Eur J Pharm Sci 18, 55-61.

Hirn, S., Semmler-Behnke, M., Schleh, C., Wenk, A., Lipka, J., Schäffler, M., Takenaka, S., Möller, W., Schmid, G., Simon, U., Kreyling, W.G., 2011. Particle size-dependent and surface charge-dependent biodistribution of gold nanoparticles after intravenous administration. Eur J Pharm Biopharm 77, 407-416.

Hirsjärvi, S., Dufort, S., Gravier, J., Texier, I., Qiao, Y., Bibette, J., Sancey, L., Josserand, V., Passirani, C., Benoit, J.-P., Coll, J.-L., 2013. Influence of size, surface coating and fine chemical composition on the in vitro reactivity and in vivo biodistribution of lipid nanocapsules versus lipid nanoemulsions in cancer models. Nanomedicine: NBM 9, 375-

405387.

Hirsjärvi, S., Passirani, C., Benoit, J.-P., 2011. Passive and active tumour targeting with nanocarriers. Curr Drug Discov Technol 8, 188-196.

Hoarau, D., Delmas, P., David, S., Roux, E., Leroux, J.-C., 2004. Novel long-circulating lipid nanocapsules. Pharm Res 21, 1783-1789.

410 Jin, Z.-H., Josserand, V., Foillard, S., Boturyn, D., Dumy, P., Favrot, M.-C., Coll, J.-L., 2007. In vivo optical imaging of integrin $\alpha_{\mathrm{v}}-\beta_{3}$ in mice using multivalent or monovalent cRGD targeting vectors. Mol Cancer 6, 41 .

Kim, J.-Y., Choi, W.I., Kim, Y.H., Tae, G., Lee, S.-Y., Kim, K., Kwon, I.C., 2010. In-vivo tumor targeting of pluronic-based nano-carriers. J Control Release 147, 109-117.

415 Kircheis, R., Ostermann, E., Wolschek, M.F., Lichtenberger, C., Magin-Lachmann, C., Wightman, L., Kursa, M., Wagner, E., 2002. Tumor-targeted gene delivery of tumor necrosis factor- $\alpha$ induces tumor necrosis and tumor regression without systemic toxicity. Cancer Gene Ther 9, 673-680. 
Kumari, A., Yadav, S.K., Yadav, S.C., 2010. Biodegradable polymeric nanoparticles based drug delivery systems. Colloid Surf B 75, 1-18.

Kursa, M., Walker, G.F., Roessler, V., Ogris, M., Roedl, W., Kircheis, R., Wagner, E., 2002. Novel shielded transferrin-polyethylene glycol-polyethylenimine/DNA complexes for systemic tumor-targeted gene transfer. Bioconjugate Chem 14, 222-231.

Lacoeuille, F., Hindré, F., Moal, F., Roux, J., Passirani, C., Couturier, O., Cales, P., Le Jeune, J.J., Lamprecht, A., Benoit, J.P., 2007. In vivo evaluation of lipid nanocapsules as a promising colloidal carrier for paclitaxel. Int J Pharm 344, 143-149.

Lamprecht, A., Saumet, J.-L., Roux, J., Benoit, J.-P., 2004. Lipid nanocarriers as drug delivery system for ibuprofen in pain treatment. Int J Pharm 278, 407-414.

Lee, H., Fonge, H., Hoang, B., Reilly, R.M., Allen, C., 2010. The effects of particle size and molecular targeting on the intratumoral and subcellular distribution of polymeric nanoparticles. Mol Pharm 7, 1195-1208.

Meng, H., Xue, M., Xia, T., Ji, Z., Tarn, D.Y., Zink, J.I., Nel, A.E., 2011. Use of size and a copolymer design feature to improve the biodistribution and the enhanced permeability and retention effect of doxorubicin-loaded mesoporous silica nanoparticles in a murine xenograft tumor model. ACS Nano 5, 4131-4144.

Mévellec, F., Tisato, F., Refosco, F., Roucoux, A., Noiret, N., Patin, H., Bandoli, G., 2002. Synthesis and characterization of the "sulfur-rich" bis (perthiobenzoato) (dithiobenzoato) technetium (III) heterocomplex. Inorg Chem 41, 598-601.

Morille, M., Montier, T., Legras, P., Carmoy, N., Brodin, P., Pitard, B., Benoit, J.-P., Passirani, C., 2010. Long-circulating DNA lipid nanocapsules as new vector for passive tumor targeting. Biomaterials 31, 321-329.

Morille, M., Passirani, C., Dufort, S., Bastiat, G., Pitard, B., Coll, J.-L., Benoit, J.-P., 2011. Tumor transfection after systemic injection of DNA lipid nanocapsules. Biomaterials 32, 23272333.

445 Müller, R.H., Shegokar, R., Keck, C.M., 2011. 20 years of lipid nanoparticles (SLN \& NLC): present state of development \& industrial applications. Curr Drug Discov Technol 8, 207 227.

Na, J.H., Koo, H., Lee, S., Min, K.H., Park, K., Yoo, H., Lee, S.H., Park, J.H., Kwon, I.C., Jeong, S.Y., Kim, K., 2011. Real-time and non-invasive optical imaging of tumor-targeting glycol chitosan nanoparticles in various tumor models. Biomaterials 32, 5252-5261.

Paillard, A., Hindré, F., Vignes-Colombeix, C., Benoit, J.-P., Garcion, E., 2010. The importance of endo-lysosomal escape with lipid nanocapsules for drug subcellular bioavailability. Biomaterials 31, 7542-7554.

Peltier, S., Oger, J.-M., Lagarce, F., Couet, W., Benoit, J.-P., 2006. Enhanced oral paclitaxel bioavailability after administration of paclitaxel-loaded lipid nanocapsules. Pharm Res 23, 1243-1250.

Perrault, S.D., Walkey, C., Jennings, T., Fischer, H.C., Chan, W.C.W., 2009. Mediating tumor targeting efficiency of nanoparticles through design. Nano Lett 9, 1909-1915.

Razkin, J., Josserand, V., Boturyn, D., Jin, Z.-h., Dumy, P., Favrot, M., Coll, J.-L., Texier, I., 2006. Activatable fluorescent probes for tumour-targeting imaging in live mice. ChemMedChem 1, 1069-1072.

Sancey, L., Dufort, S., Josserand, V., Keramidas, M., Righini, C., Rome, C., Faure, A.C., Foillard, S., Roux, S., Boturyn, D., Tillement, O., Koenig, A., Boutet, J., Rizo, P., Dumy, P., Coll, J.L., 2009. Drug development in oncology assisted by noninvasive optical imaging. Int J Pharm 379, 309-316.

Schädlich, A., Caysa, H., Mueller, T., Tenambergen, F., Rose, C., Göpferich, A., Kuntsche, J., Mäder, K., 2011a. Tumor accumulation of NIR fluorescent PEG-PLA nanoparticles: impact of particle size and human xenograft tumor model. ACS Nano 5, 8710-8720. 
Schädlich, A., Hoffmann, S., Mueller, T., Caysa, H., Rose, C., Göpferich, A., Li, J., Kuntsche, J., Mäder, K., 2012. Accumulation of nanocarriers in the ovary: a neglected toxicity risk? J Control Release 160, 105-112.

Schädlich, A., Rose, C., Kuntsche, J., Caysa, H., Mueller, T., Göpferich, A., Mäder, K., 2011 b. How stealthy are PEG-PLA nanoparticles? An NIR in vivo study combined with detailed size measurements. Pharm Res 28, 1995-2007.

Sonavane, G., Tomoda, K., Makino, K., 2008. Biodistribution of colloidal gold nanoparticles after intravenous administration: effect of particle size. Colloid Surf B 66, 274-280.

Sun, X., Rossin, R., Turner, J.L., Becker, M.L., Joralemon, M.J., Welch, M.J., Wooley, K.L., 2005. An assessment of the effects of shell cross-linked nanoparticle size, core composition, and surface PEGylation on in vivo biodistribution. Biomacromolecules 6, 2541-2554.

480 Torchilin, V., 2007. Micellar nanocarriers: Pharmaceutical perspectives. Pharm Res 24, 1-16.

Torchilin, V.P., 2005. Recent advances with liposomes as pharmaceutical carriers. Nat Rev Drug Discov 4, 145-160.

Vanpouille-Box, C., Lacoeuille, F., Belloche, C., Lepareur, N., Lemaire, L., LeJeune, J.-J., Benoit, J.-P., Menei, P., Couturier, O.F., Garcion, E., Hindré, F., 2011a. Tumor eradication in rat glioma and bypass of immunosuppressive barriers using internal radiation with 188Re-lipid nanocapsules. Biomaterials 32, 6781-6790.

Vanpouille-Box, C., Lacoeuille, F., Roux, J., Aubé, C., Garcion, E., Lepareur, N., Oberti, F., Bouchet, F., Noiret, N., Garin, E., Benoit, J.-P., Couturier, O., Hindré, F., 2011b. Lipid nanocapsules loaded with rhenium-188 reduce tumor progression in a rat hepatocellular carcinoma model. PLoS ONE 6, e16926.

Weyland, M., Manero, F., Paillard, A., Grée, D., Viault, G., Jarnet, D., Menei, P., Juin, P., Chourpa, I., Benoit, J.P., Grée, R., Garcion, E., 2011. Mitochondrial targeting by use of lipid nanocapsules loaded with SV30, an analogue of the small-molecule Bcl-2 inhibitor HA14-1. J Control Release 151, 74-82.

495 Vonarbourg, A., Passirani, C., Saulnier, P., Benoit, J.-P., 2006. Parameters influencing the stealthiness of colloidal drug delivery systems. Biomaterials 27, 4356-4373.

Vonarbourg, A., Saulnier, P., Passirani, C., Benoit, J.-P., 2005. Electrokinetic properties of noncharged lipid nanocapsules: Influence of the dipolar distribution at the interface. Electrophoresis 26, 2066-2075.

500 Yang, Z., Leon, J., Martin, M., Harder, J.W., Zhang, R., Liang, D., Lu, W., Tian, M., Gelovani, J.G., Qiao, A., Li, C., 2009. Pharmacokinetics and biodistribution of near-infrared fluorescence polymeric nanoparticles. Nanotechnol 20, 165101.

Yang, Z., Zheng, S., Harrison, W.J., Harder, J., Wen, X., Gelovani, J.G., Qiao, A., Li, C., 2007. Long-circulating near-infrared fluorescence core-cross-linked polymeric micelles: synthesis, characterization, and dual nuclear/optical imaging. Biomacromolecules 8, 3422-3428.

Zou, J., Saulnier, P., Perrier, T., Zhang, Y., Manninen, T., Toppila, E., Pyykkö, I., 2008. Distribution of lipid nanocapsules in different cochlear cell populations after round window membrane permeation. J Biomed Mat Res B 87B, 10-18. 


\section{Figure captions}

Table 1. Compositions of LNC of different sizes.

\begin{tabular}{lcccccc}
\hline & $\begin{array}{c}\text { Solutol } \\
(\mathrm{mg})\end{array}$ & $\begin{array}{c}\text { Lipoid® } \\
(\mathrm{mg})\end{array}$ & $\begin{array}{c}\text { Labrafac® } \\
(\mathrm{mg})\end{array}$ & $\begin{array}{c}\mathrm{NaCl} \\
(\mathrm{mg})\end{array}$ & $\begin{array}{c}\text { Water } \\
(\mathrm{mg})\end{array}$ & $\begin{array}{c}\text { Concentration } \\
(\mathrm{mg} / \mathrm{mL})\end{array}$ \\
\hline LNC 25 nm & 645 & 25 & 282 & 30 & 685 & 168 \\
LNC 50 nm & 282 & 25 & 343 & 30 & 987 & 115 \\
LNC 100 nm & 161 & 25 & 403 & 30 & 1048 & 104 \\
\hline
\end{tabular}

515

Table 2. Size and $\zeta$-potential of ${ }^{99 \mathrm{~m}} \mathrm{Tc}-\mathrm{LNC}$ measured in physiological PBS.

\begin{tabular}{llll}
\hline & Diameter $(\mathrm{nm})$ & PdI & $\zeta$-Potential $(\mathrm{mV})$ \\
\hline LNC 25 nm & $25 \pm 2$ & 0.08 & $-3 \pm 1$ \\
LNC 50 nm & $51 \pm 1$ & 0.03 & $-4 \pm 1$ \\
LNC 100 nm & $93 \pm 1$ & 0.04 & $-6 \pm 1$ \\
\hline
\end{tabular}




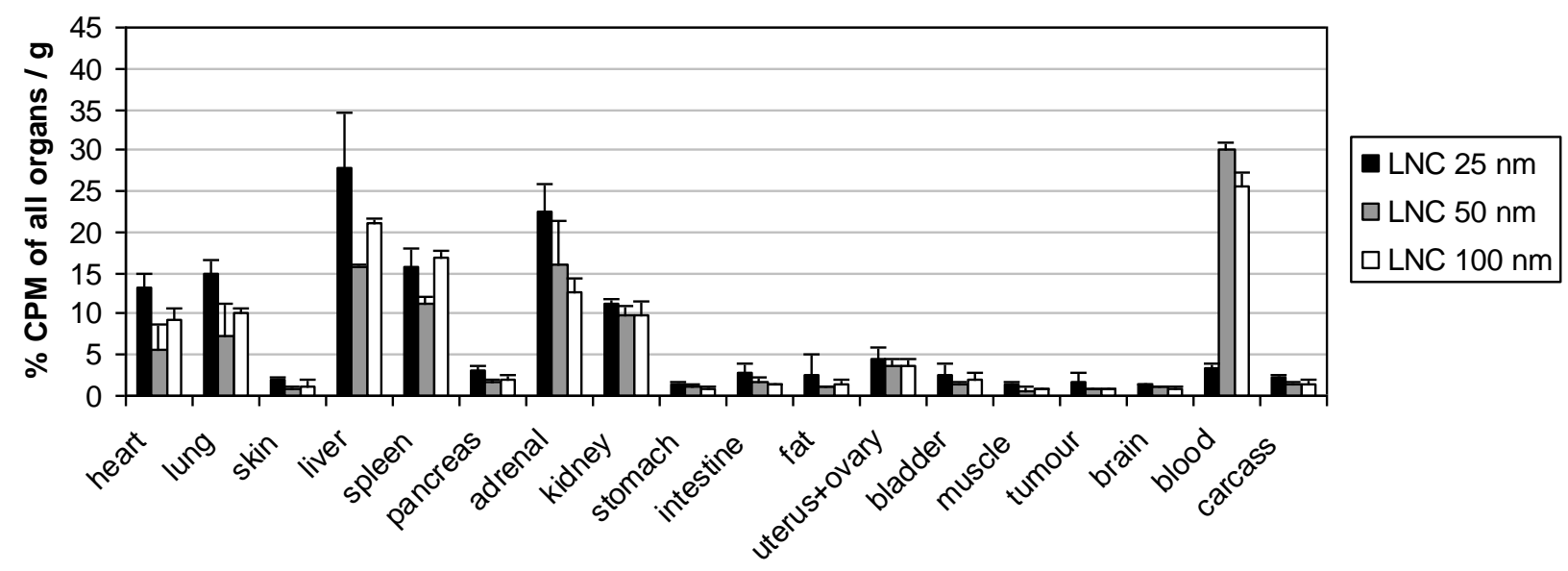

$4 \mathrm{~h}$

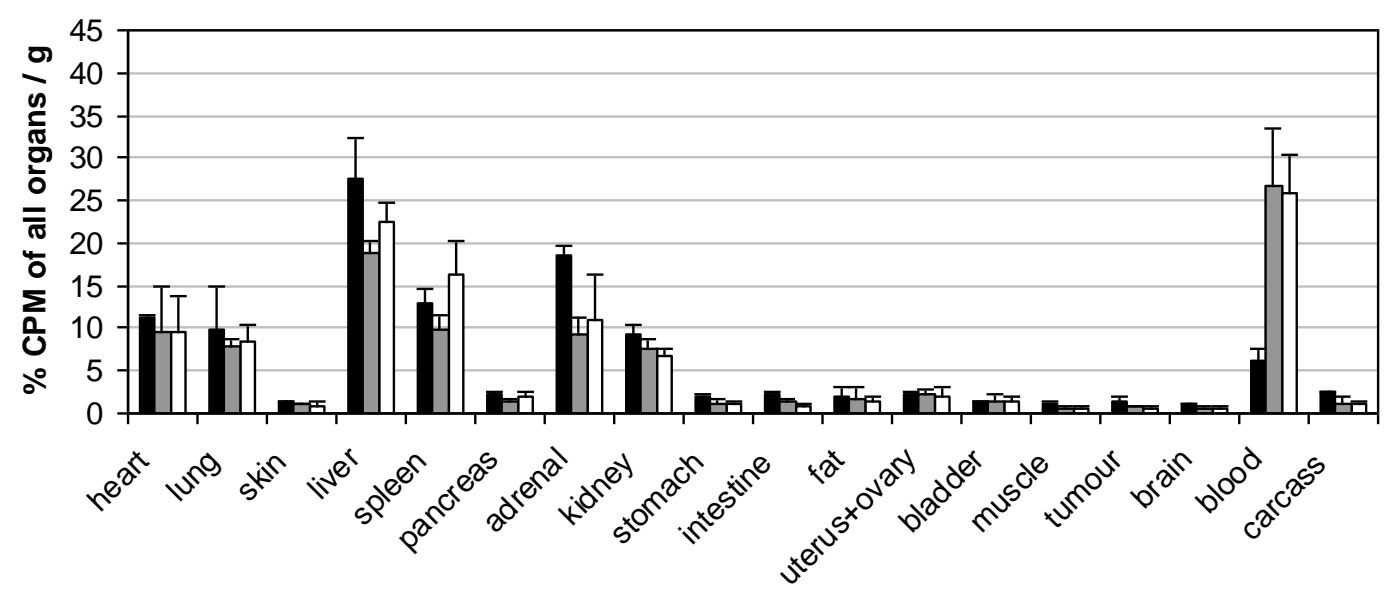

- LNC $25 \mathrm{~nm}$ $\square$ LNC $50 \mathrm{~nm}$ $\square$ LNC $100 \mathrm{~nm}$

$24 \mathrm{~h}$

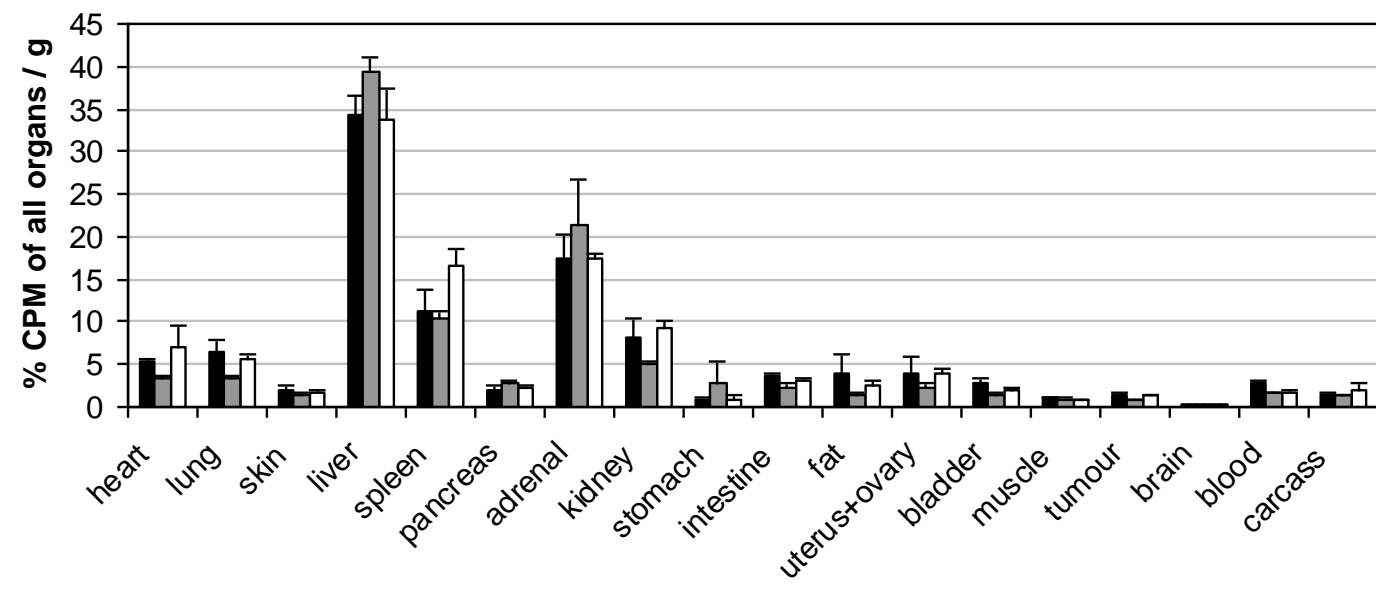

- LNC $25 \mathrm{~nm}$ $\square$ LNC $50 \mathrm{~nm}$ $\square$ LNC $100 \mathrm{~nm}$

520 Figure 1. Biodistribution of 25, 50, and $100 \mathrm{~nm}{ }^{99 m} \mathrm{Tc}-\mathrm{LNC}$ in different organs $1.5 \mathrm{~h}, 4 \mathrm{~h}$, and $24 \mathrm{~h}$ after intravenous injection. $\mathrm{CPM}=$ counts per minute 


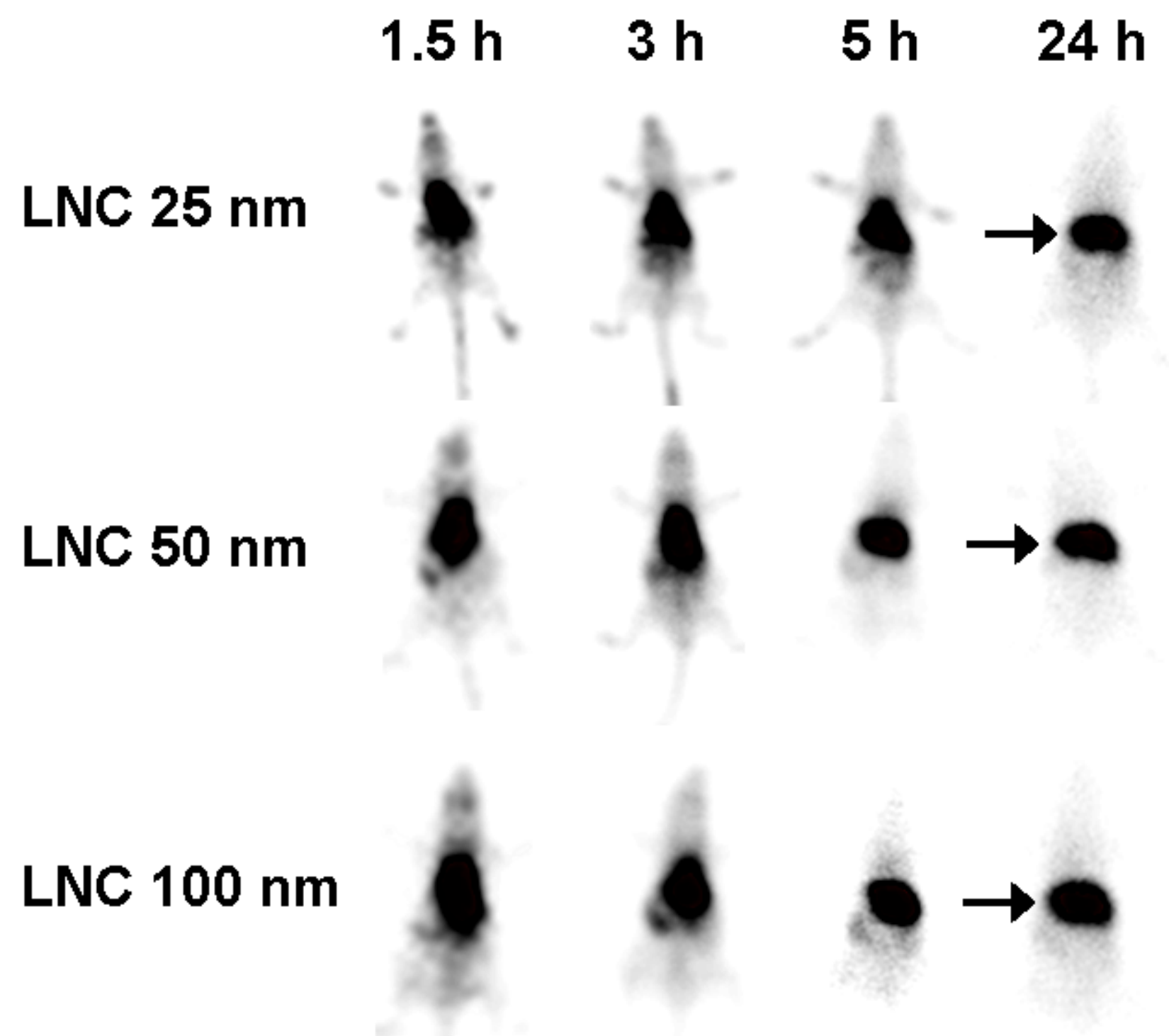

525 Figure 2. $\gamma$-Scintigraphic images expressing biodistribution of 25,50 , and $100 \mathrm{~nm}{ }^{99 \mathrm{~m}} \mathrm{Tc}-\mathrm{LNC}$ in mice $1.5 \mathrm{~h}, 3 \mathrm{~h}, 5 \mathrm{~h}$, and $24 \mathrm{~h}$ after intravenous injection. Arrows indicate the liver. 


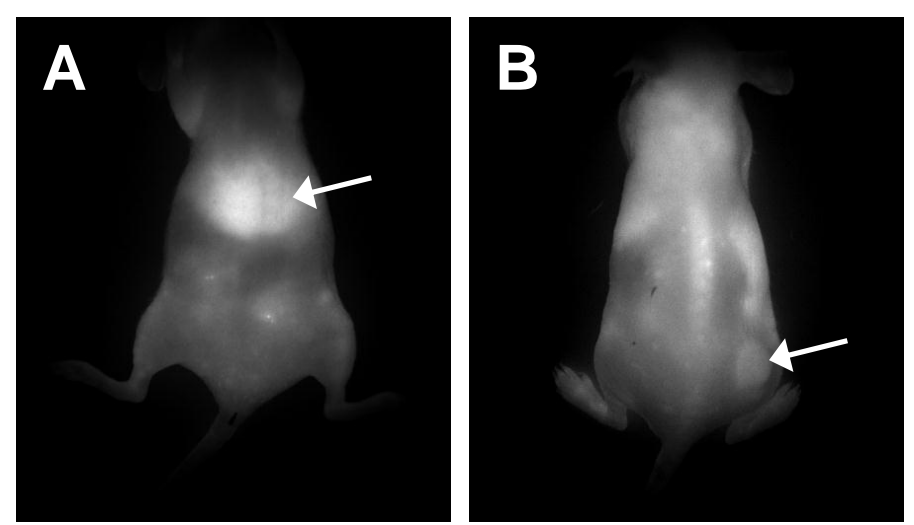

Figure 3. LNC biodistribution by optical imaging. Fluorescence images of a mouse $24 \mathrm{~h}$ after an i.v. injection of a $50 \%-50 \%$ mixture of $50 \mathrm{~nm}{ }^{99 m} \mathrm{Tc}-\mathrm{LNC}$ and $50 \mathrm{~nm}$ DiD-LNC. Mouse lying on its back (A, arrow indicates the liver) and belly (B, arrow indicates the tumour). 
A

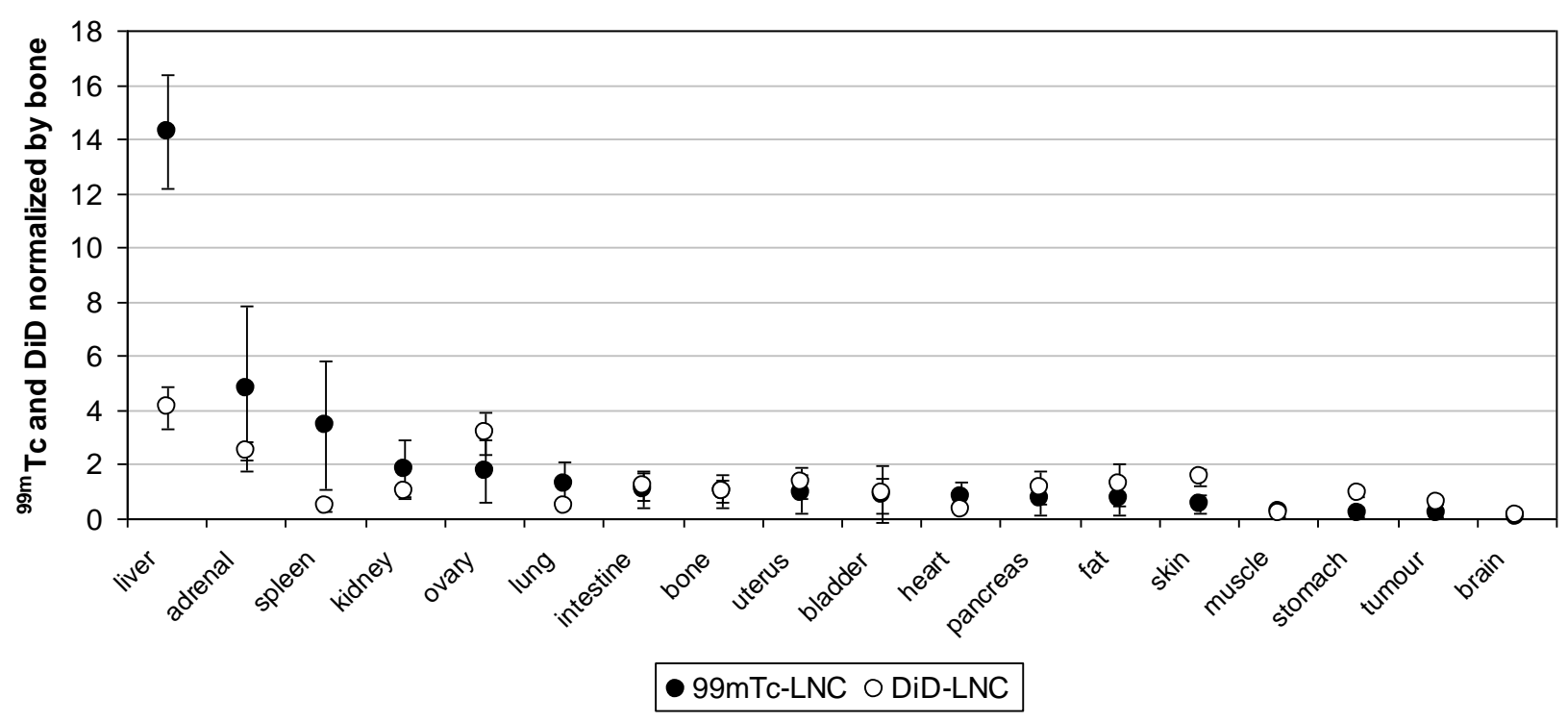

B

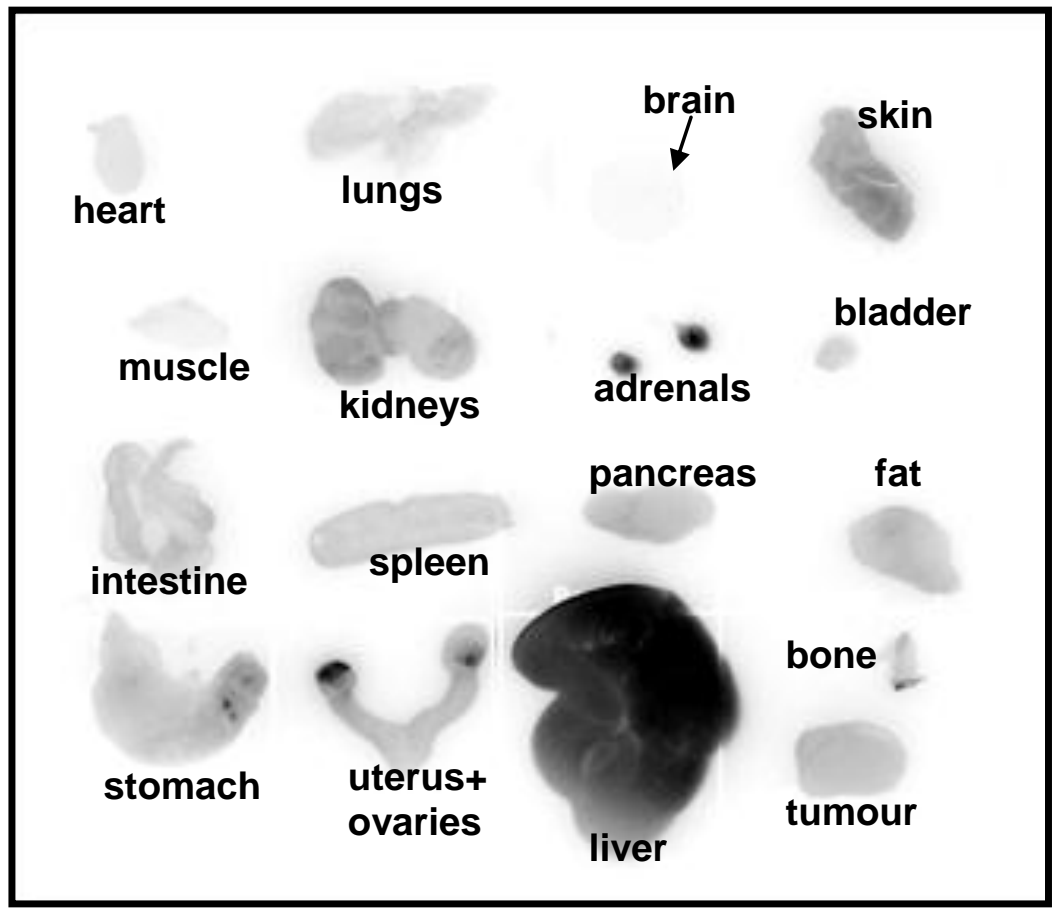

Figure 4. Comparison of the two detection techniques, radioactivity and fluorescence intensity, for quantification of organ distribution of the 50\%-50\% mixture (50 nm DiD-LNC and $\left.{ }^{99 \mathrm{~m}} \mathrm{Tc}-\mathrm{LNC}\right) 24$ $540 \mathrm{~h}$ after injection (A). Example of the dissected organs visualized by a fluorescence camera (B). 